\title{
The Effect of Proflavine on HeLa Cells
}

\author{
By J. W. WATTS AND M. A. F. DAVIS \\ John Innes Institute, Bayfordbury, Hertford, Herts.
}

(Received 11 January 1966)

\begin{abstract}
1. The effect of proflavine on the metabolism of RNA, DNA and protein of HeLa cells was studied. 2. The synthesis of RNA, DNA and protein was progressively inhibited by concentrations of proflavine up to $43 \mu \mathrm{M}$. 3. There was no simple relationship between the degrees of inhibition of synthesis of RNA, DNA and protein by increasing concentrations of proflavine: the synthesis of RNA was most readily inhibited, and the synthesis of protein was relatively insensitive. 4. A concentration of $22 \mu \mathrm{M}$-proflavine inhibited synthesis of RNA and DNA and caused a progressive loss of RNA from both nucleus and cytoplasm without any accompanying loss of DNA or dry weight from the cells. 5. The rapidly labelled RNA in the nucleus was preferentially degraded and was not transferred in a stable form to the cytoplasm.
\end{abstract}

Proflavine, acridine orange and many other acridine derivatives interact with nucleic acids to form metachromatic complexes (Morthland, De Bruyn \& Smith, 1954), and some of the acridine dyes have been used as stains for nucleic acids in both living and fixed material (De Bruyn, Farr, Banks \& Morthland, 1953; Armstrong, 1956 ; Bertalanffy \& Bickis, 1956; Wolf \& Aronson, 1960). The interaction of the acridines with nucleic acids shows some specificity and the characteristic fluorescences produced by acridine orange in fixed tissues can be prevented or much decreased by prior treatment of the tissue with deoxyribonuclease and ribonuclease (Armstrong, 1956; Bertalanffy \& Bickis, 1956). Wolf \& Aronson (1960) found concentrations of acridine orange that produced the green nuclear fluorescence characteristic of the interaction of acridine orange with DNA, but still permitted the continued growth of animal cells. Replication of RNA-containing viruses of animal cells also occurs in similar conditions; the new virus contains proflavine but possesses normal infectivity (Schaffer, 1962; Schaffer \& Hackett, 1963). However, a high degree of specificity of action is unlikely since the acridine dyes also interact readily with many polyanions, e.g. polyphosphates and mucopolysaccharides (Bradley \& Wolf, 1959; Saunders, 1964).

Scholtissek (1965) has investigated the nature of the small amount of RNA synthesis that occurs in chick-embryo cells in the presence of high concentrations of proflavine, but little is known about the more general effects of acridine dyes on the metabolism of animal cells. The present paper describes the effect of proflavine on the synthesis of nucleic acids and protein in HeLa cells.

\section{EXPERIMENTAL}

The conditions used in the culture of HeLa cells were as described by Watts (1964a). Acridine orange and proflavine (British Drug Houses Ltd., Poole, Dorset) were used without further purification. Solutions of acridines were prepared immediately before use and kept in the dark, as were cultures containing acridines.

Following the work of Wolf \& Aronson (1960), the concentrations of proflavine investigated in detail lay between 4 and $43 \mu \mathrm{M}$. The effectiveness of the individual acridines depends on pH (Hirota, 1960; Robbins \& Marcus, 1963) and the cultures used were therefore grown so that the $\mathrm{pH}$ was $7 \cdot 4 \pm 0 \cdot 2$. The amount of material in the cultures that was able to absorb dye out of solution was partially controlled by working under standard conditions of culture so that the amount of serum protein and the cell density in the cultures were approximately constant from experiment to experiment. Concentrations of proflavine up to $22 \mu \mathrm{M}$ had no marked effects during the first $8 \mathrm{hr}$. on the general morphology of HeLa cells grown as monolayers on glass and there was no tendency for the cells to come off the glass. Higher concentrations of the dye were markedly toxic. Proflavine was used for detailed study, but experiments with acridine orange gave similar results.

Radioactive compounds. [ ${ }^{-14} \mathrm{C}$ ]Adenine $(28 \mathrm{mc} / \mathrm{m}-\mathrm{mole})$, DL-[1-14 C]valine $(4 \mathrm{mc} / \mathrm{m}-\mathrm{mole})$ and [2-14 C]thymidine (30 mc/m-mole) were obtained from The Radiochemical Centre, Amersham, Bucks. The methods used to count radioactivity were as described by Watts (1964a).

Measurement of the dry weights of cultures. A $25 \mathrm{ml}$. sample of culture was spun at $220 \mathrm{~g}$ for $3 \mathrm{~min}$. and the pellet was washed with $0 \cdot 85 \% \mathrm{NaCl}$ soln., extracted with $5 \mathrm{ml}$. of $0.6 \mathrm{~N}$-trichloroacetic acid for $30 \mathrm{~min}$. at $0^{\circ}$, transferred to tared tubes and dried for $4 \mathrm{hr}$. at $105^{\circ}$. The tubes were allowed to cool in a desiccator and weighed.

Preparation of nucleic acid fractions. Nuclear and cytoplasmic RNA were separated by the method of Harris \& Watts (1962). The specific activity of adenine in nuclear 
and cytoplasmic RNA was determined by the method of Watts (1964a).

Measurement of the amount of nucleic acid. A $25 \mathrm{ml}$. sample of culture was spun at $220 \mathrm{~g}$ for $3 \mathrm{~min}$. The cells were washed with $0 \cdot 85 \% \mathrm{NaCl}$ soln. and then extracted with $5 \mathrm{ml}$. of $0.6 \mathrm{~N}$-trichloroacetic acid for $30 \mathrm{~min}$. at $0^{\circ}$. The pellet was washed with water and extracted with aq. $70 \%(v / v)$ ethanol for $30 \mathrm{~min}$. at $50^{\circ}$ followed by ethanolether $(1: 1, v / v)$ for $30 \mathrm{~min}$. at $40^{\circ}$. The residue was then hydrolysed with $2 \mathrm{ml}$. of $0.3 \mathrm{~N}-\mathrm{KOH}$ for $18 \mathrm{hr}$. at $37^{\circ}$. The solution was acidified to $\mathrm{pH} 1$ with $10 \mathrm{~N}-\mathrm{HClO}_{4}$ at $0^{\circ}$ and spun at $2000 \mathrm{~g}$ for $15 \mathrm{~min}$. at $0^{\circ}$. The supernatant contained the total RNA fraction. The pellet containing the DNA was washed with water and extracted with $2 \mathrm{ml}$. of $0.6 \mathrm{~N}$ trichloroacetic acid for $30 \mathrm{~min}$. at $90^{\circ}$, spun at $2000 \mathrm{~g}$ for $5 \mathrm{~min}$. and the supernatant, containing the DNA fraction, was collected.

When the amounts of nuclear and cytoplasmic RNA were determined, $25 \mathrm{ml}$. of culture was spun at $220 \mathrm{~g}$ for 3 min., the cells were washed with $0.85 \% \mathrm{NaCl}$ soln. and then extracted with $5 \mathrm{ml}$. of phenol-saturated water containing about $0.2 \mathrm{ml}$. of water-saturated phenol for about $1 \mathrm{hr}$. at $4^{\circ}$. The mixture was spun at $2500 \mathrm{~g}$ for $30 \mathrm{~min}$. at $4^{\circ}$. The supernatant, containing the cytoplasmic RNA, was acidified to $\mathrm{pH} 1$ with $\mathrm{N}-\mathrm{HCl}$ and spun at $2000 \mathrm{~g}$ for $15 \mathrm{~min}$. at $0^{\circ}$. The precipitate of cytoplasmic RNA was washed by decantation with $10 \mathrm{ml}$. of ice-cold $0.1 \mathrm{~N}-\mathrm{HCl}$ and then hydrolysed with $2 \mathrm{ml}$. of $0.3 \mathrm{~N}-\mathrm{KOH}$ for $18 \mathrm{hr}$. at $37^{\circ}$. The solution was acidified to $\mathrm{pH} 1$ with $10 \mathrm{~N}-\mathrm{HClO}_{4}$ at $0^{\circ}$ and spun at $2000 \mathrm{~g}$ for $15 \mathrm{~min}$. at $0^{\circ}$. The supernatant, containing the cytoplasmic RNA fraction, was collected. The pellet from the phenol extraction was washed with water and extracted first with aq. $70 \%(v / v)$ ethanol for $30 \mathrm{~min}$. at $50^{\circ}$ and then with ethanol-ether $(1: 1, \mathrm{v} / \mathrm{v})$ for $30 \mathrm{~min}$. at $40^{\circ}$. The pellet was then hydrolysed with $2 \mathrm{ml}$. of $0.3 \mathrm{~N}-\mathrm{KOH}$ for $18 \mathrm{hr}$. at $37^{\circ}$. The DNA and protein were precipitated by acidifying the solution to $\mathrm{pH} 1$ with $10 \mathrm{~N}-$ $\mathrm{HClO}_{4}$ at $0^{\circ}$. The mixture was spun at $2000 \mathrm{~g}$ for $15 \mathrm{~min}$. at $0^{\circ}$ and the supernatant, containing the nuclear RNA fraction, was collected.

The amounts of RNA and DNA in the different fractions were determined by diluting the solutions to $3.5 \mathrm{ml}$. with water and measuring $E_{260}$ in $1 \mathrm{~cm}$. cells in a Hilger Uvispek (model H.700). Samples of the solutions were taken and the radioactivity was counted in the usual way.

Measurement of the radioactivity in the protein fraction. When incorporation of precursors into cell protein was studied, the cells were grown in medium containing DL[1.14C]valine $(0.2 \mathrm{~mm})$ (Harris \& Jahnz, 1958). A $25 \mathrm{ml}$. sample of culture was spun at $220 \mathrm{~g}$ for $3 \mathrm{~min}$. and the cells were washed with $0.85 \% \mathrm{NaCl}$ soln. and then extracted with $5 \mathrm{ml}$. of $0 \cdot 6 \mathrm{~N}$-trichloroacetic acid for $30 \mathrm{~min}$. at $0^{\circ}$. The residue was washed with water and extracted with aq. $70 \%(v / v)$ ethanol for $30 \mathrm{~min}$. at $50^{\circ}$ followed by ethanol-ether $(1: 1, v / v)$ for $30 \mathrm{~min}$. at $40^{\circ}$. The residue was then heated in a sealed tube with $0.3 \mathrm{ml}$. of $6 \mathrm{~N}-\mathrm{HCl}$ for $1 \mathrm{hr}$. at $105^{\circ}$ to dissolve the protein. The tube was opened and the radioactivity in a sample of the solution was counted.

\section{RESULTS}

Effect of proflavine on the incorporation of radioactive precursors into nucleic acids and proteins. The effects of different concentrations of proflavine on the incorporation of $\left[8-{ }^{14} \mathrm{C}\right]$ adenine into RNA, $\left[2-{ }^{14} \mathrm{C}\right]$ thymidine into DNA and $\mathrm{DL}-\left[1-{ }^{14} \mathrm{C}\right]$ valine into protein are shown in Figs. 1-3. The curves show that proflavine inhibited the incorporation of precursors into RNA, DNA and protein without appreciable lag.

RNA synthesis was more sensitive than DNA synthesis, but incorporation of valine into protein was relatively resistant to proflavine and continued at a diminished rate even in the presence of $22 \mu \mathrm{M}$ proflavine, which rapidly and almost completely inhibited the incorporation of precursors into RNA and DNA.

Effect of proflavine on the amounts of dry weight and nucleic acids of HeLa cells. When the cells were grown in medium containing proflavine $(22 \mu \mathrm{M})$, the dry weight of the cells showed no significant change over a period of $6 \mathrm{hr}$. (Table 1). The amount of DNA in the cells also showed no significant change during this time (Fig. 4). There was, however, a progressive fall in the amounts of both nuclear and cytoplasmic RNA in the cells, and about $30 \%$ of the RNA in both fractions was converted into acid-soluble material during $6 \mathrm{hr}$. (Fig. 4).

Effect of proflavine on the incorporation of $\left[8-{ }^{14} \mathrm{C}\right]$ adenine into $R N A$. Fig. 1 shows the incorporation of [ $\left.8 \cdot{ }^{14} \mathrm{C}\right]$ adenine into total RNA. Since the amount

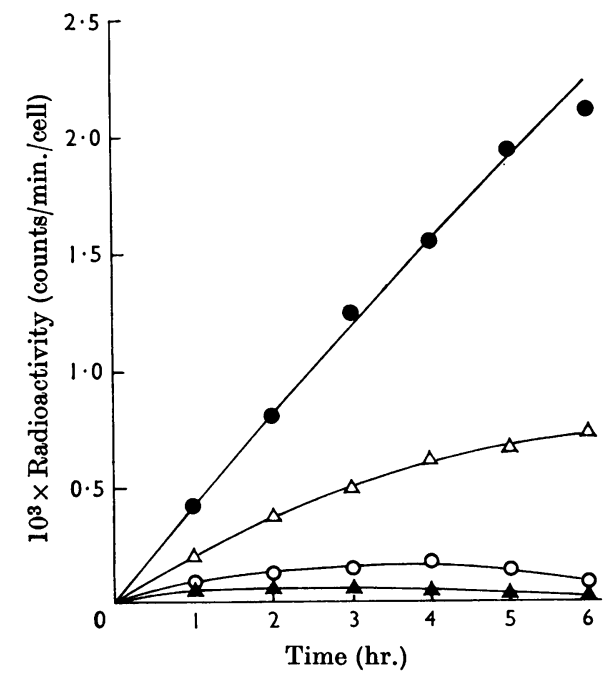

Fig. 1. Effect of proflavine on the incorporation of [8-14C]adenine into the RNA of HeLa cells. Cultures of cells were grown in medium containing $\left[8-{ }^{14} \mathrm{C}\right]$ adenine $(0.1 \mathrm{mM})$ (initial specific radioactivity $5 \times 10^{5}$ counts $/ \mathrm{min} . / \mu$ mole) and different concentrations of proflavine. Samples were taken at intervals and the radioactivity in RNA was determined. ๑, Control (no proflavine); $\Delta, 4 \mu \mathrm{M}$-proflavine; ○, $22 \mu \mathrm{M}$-proflavine; $\Delta, \mathbf{4 3} \mu \mathrm{M}$-proflavine. 


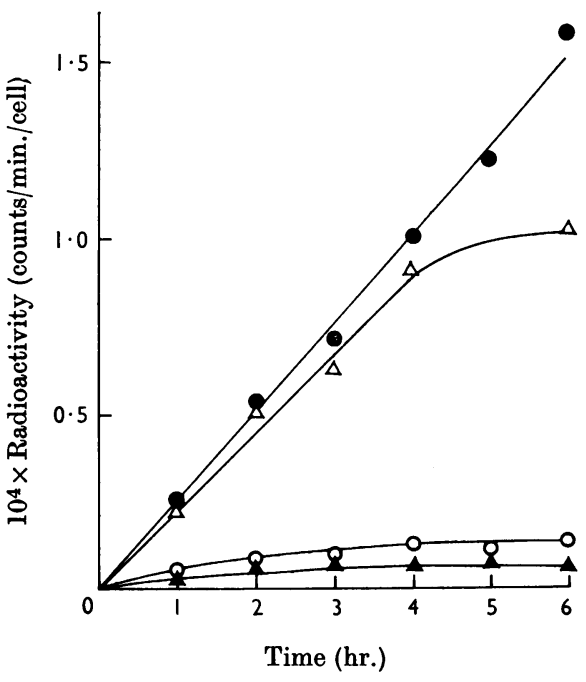

Fig. 2. Effect of proflavine on the incorporation of $[2-14 \mathrm{C}]$ thymidine into the DNA of HeLa cells. Cultures of cells were grown in medium containing $[2-14 \mathrm{C}]$ thymidine $(0.05 \mathrm{~mm})$ (initial specific radioactivity $5.5 \times 10^{5}$ counts/ min. $/ \mu \mathrm{mole}$ ) and different concentrations of proflavine. Samples were taken at intervals and the radioactivity in DNA was determined. $\bullet$, Control (no proflavine); $\triangle, 4 \mu \mathrm{M}$ proflavine; $\bigcirc, 22 \mu \mathrm{M}$-proflavine; $\Delta, 43 \mu \mathrm{M}$-proflavine.

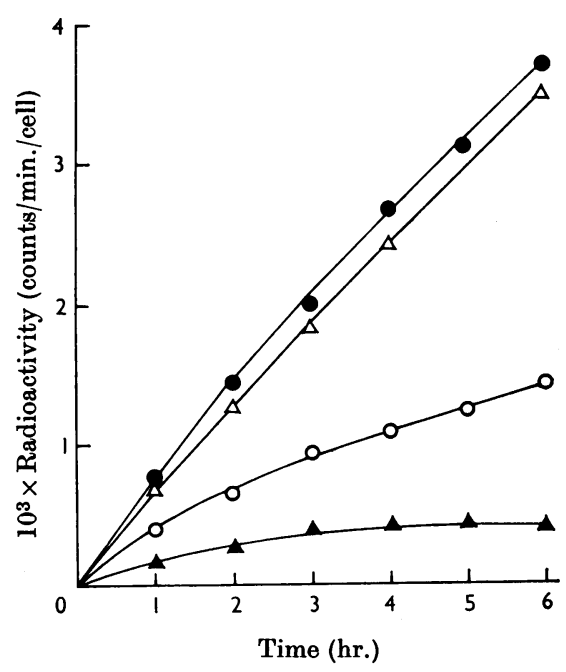

Fig. 3. Effect of proflavine on the incorporation of DL[1.14 C]valine into the protein of HeLa cells. Cultures of cells were grown in medium containing $\mathrm{DL}-\left[1-{ }^{14} \mathrm{C}\right]$ valine (initial specificity radioactivity $2 \times 10^{6}$ counts $/ \mathrm{min} . / \mu$ mole) and different concentrations of proflavine. Samples were taken at intervals and the radioactivity in protein was determined. ๑, Control (no proflavine); $\Delta, 4 \mu \mathrm{M}$-proflavine; O, $22 \mu \mathrm{M}$-proflavine; $\Delta, 43 \mu \mathrm{M}$-proflavine.

of RNA in the culture fell during the experiment, the specific activities of the individual bases in RNA were also determined. Figs. 5 and 6 show the effect of $22 \mu \mathrm{M}$-proflavine on the incorporation of $\left[8-{ }^{14} \mathrm{C}\right]$ adenine into nuclear and cytoplasmic RNA and the corresponding specific activities of the adenine isolated from nuclear and cytoplasmic RNA. The two groups of curves are not strictly comparable since the values for total radioactivity also included a contribution from the radioactivity in guanine (Watts, 1964a).

Effect of proflavine on the retention of $[8-14 \mathrm{C}]$ adenine in RNA. HeLa cells contain several fractions of RNA, which are synthesized at different rates. These fractions can be demonstrated by determining the rate at which radioactivity is lost from RNA when cells that have been labelled for various periods of time are transferred to nonradioactive medium (Watts, 1964b). When cells are grown in medium containing $\left[8-{ }^{14} \mathrm{C}\right]$ adenine, radioactivity at first almost entirely enters the

Table 1. Effect of proflavine on the dry weight of HeLa cells

The cells were grown in medium containing proflavine $(22 \mu \mathrm{M})$. Samples were taken at intervals and the dry weight of the cells was determined.

Time from introduction of proflavine (hr.)

$\begin{array}{ll}0 & 16 \cdot 4 \\ 0 \cdot 5 & 16 \cdot 6 \\ 1 \cdot 0 & 15 \cdot 8 \\ 2 \cdot 0 & 16 \cdot 6 \\ 3 \cdot 0 & 18 \cdot 9 \\ 4 \cdot 5 & 15 \cdot 7 \\ 5 \cdot 5 & 15 \cdot 8\end{array}$

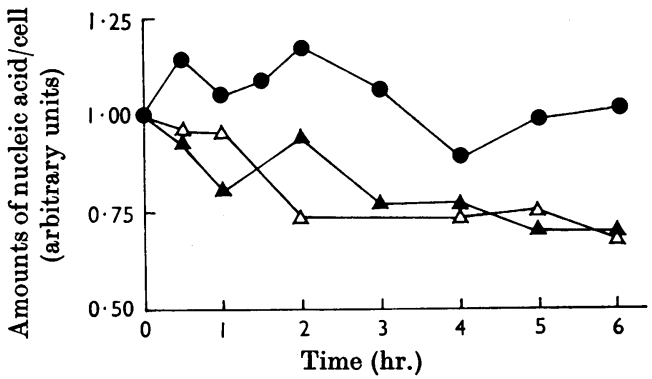

Fig. 4. Effect of proflavine on the amount of nucleic acid in HeLa cells. The cells were grown in medium containing proflavine $(22 \mu \mathrm{M})$. Samples were taken at intervals and the relative amounts of DNA and nuclear and cytoplasmic RNA were determined. $\bullet, D N A ; \Delta$, nuclear RNA; $\Delta$, cytoplasmic RNA. 


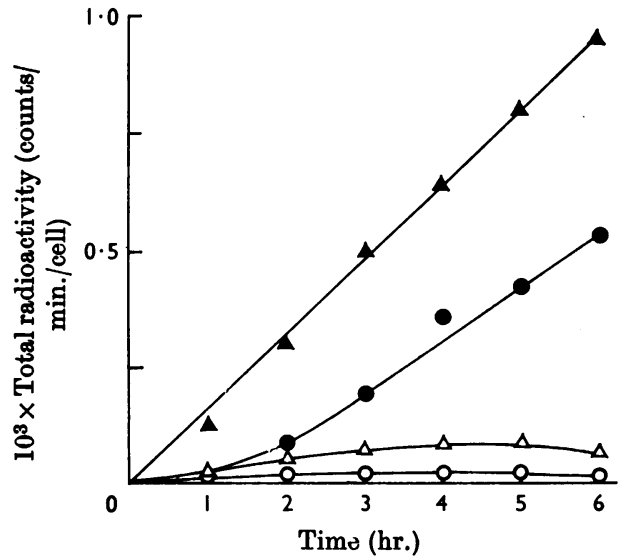

Fig. 5. Effect of proflavine on the incorporation of [8.14 C]adenine into the nuclear and cytoplasmic RNA of HeLa cells. The cells were grown in medium containing [8-14C]adenine $(0.1 \mathrm{~mm})$ (initial specific radioactivity $4 \times 10^{5}$ counts $\left./ \mathrm{min} . / \mu \mathrm{mole}\right)$ and proflavine $(22 \mu \mathrm{M})$. Samples were taken at intervals and the total radioactivity in nuclear and cytoplasmic RNA was determined. $\Delta$, Nuclear RNA of the control culture without added proflavine; $\Delta$, nuclear RNA in the presence of proflavine; 0 , cytoplasmic RNA of the control culture without added proflavine; $O$, cytoplasmic RNA in the presence of proflavine.

small fraction of nuclear RNA that turns over most rapidly. However, the radioactivity in the less rapidly labelled fractions of nuclear and cytoplasmic RNA increases as the period of labelling is lengthened until after about $12-18 \mathrm{hr}$. most of the radioactivity is in the fractions of RNA that turn over more slowly. Studies of the retention of radioactivity in RNA thus provided a means by which the effect of proflavine on the different fractions of RNA could be examined.

When the retention of radioactivity in RNA was studied in cells that had been grown for $20 \mathrm{~min}$. in medium containing [8.14C]adenine and then transferred to non-radioactive medium the results shown in Figs. 7 and 8 were obtained. The curves have several noteworthy features.

(i) The net loss of nuclear RNA produced by proflavine (Fig. 4) presumably involved the breakdown of at least part of the more slowly labelled fraction of nuclear RNA. Fig. 8 shows, however, that the preferential loss of rapidly labelled RNA observed in the control culture continued in the presence of proflavine.

(ii) Cells that have been grown in medium containing $\left[8-{ }^{14} \mathrm{C}\right]$ adenine rapidly accumulate large intracellular 'pools' of acid-soluble radioactive precursors of RNA. These 'pools' cannot be washed out of the cells, and when the cells are transferred to non-radioactive medium radio-

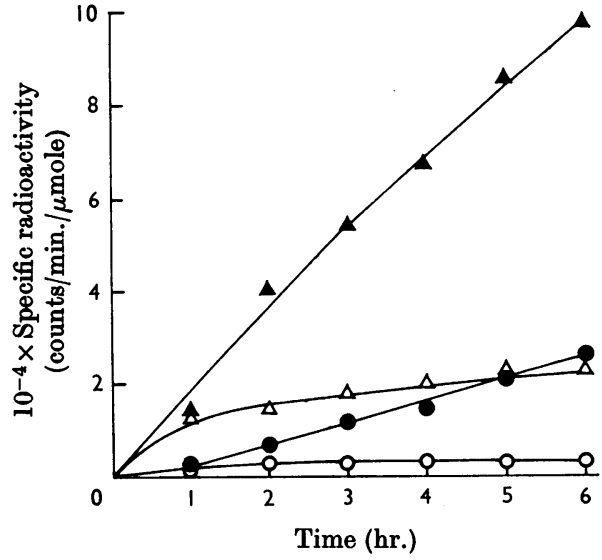

Fig. 6. Effect of proflavine on the incorporation of $[8.14 \mathrm{C}]$ adenine into the adenine of nuclear and cytoplasmic RNA of HeLa cells. The experiment was that described in the legend to Fig. 5. The specific radioactivity of adenine in nuclear and cytoplasmic RNA was determined. $\Delta$, Nuclear-RNA adenine of the control culture without added proflavine; $\Delta$, nuclear-RNA adenine in the presence of proflavine; $\ominus$, cytoplasmic-RNA adenine of the control culture without added proflavine; $O$, cytoplasmic-RNA adenine in the presence of proflavine.

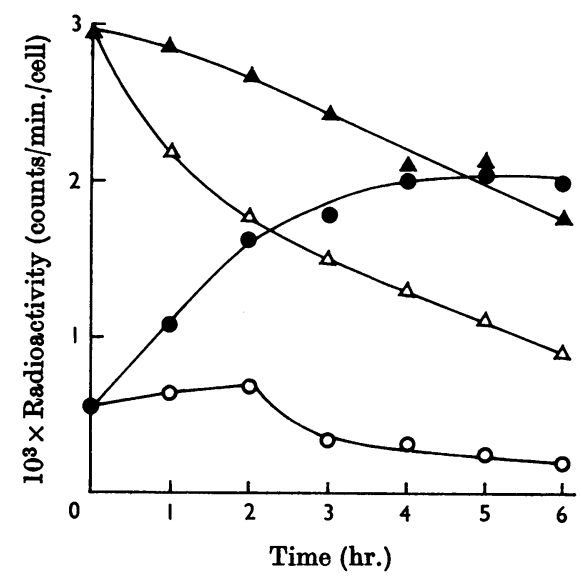

Fig. 7. Effect of proflavine on the retention of radioactivity in the RNA of HeLa cells. The cells were grown for $20 \mathrm{~min}$. in medium containing [8.14 C]adenine $(0.01 \mathrm{~mm}$ ) (initial specific radioactivity $2.5 \times 10^{7}$ counts $\left./ \mathrm{min} . / \mu \mathrm{mole}\right)$ and then transferred to non-radioactive medium containing adenosine (1 $\mathrm{mM})$, guanosine $(0.2 \mathrm{mM})$ and proflavine $(22 \mu \mathrm{M})$. Samples were taken at intervals and the total radioactivity in nuclear and cytoplasmic RNA was determined. $\Delta$, Nuclear RNA of the control culture without added proflavine; $\triangle$, nuclear RNA in the presence of proflavine; $\bullet$, cytoplasmic RNA of the control culture without added proflavine; $O$, cytoplasmic RNA in the presence of proflavine. 


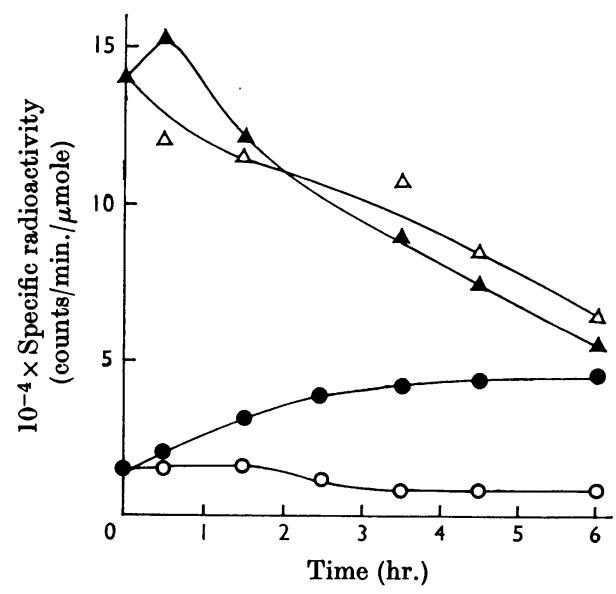

Fig. 8. Effect of proflavine on the retention of $[8-14 \mathrm{C}]$ adenine in the RNA of HeLa cells. The experiment was that described in the legend to Fig. 7. The specific radioactivity of the adenine in nuclear and cytoplasmic RNA was determined. $\Delta$, Nuclear-RNA adenine of the control culture without added proflavine; $\triangle$, nuclear-RNA adenine in the presence of proflavine; $\bullet$, cytoplasmic-RNA adenine of the control culture without added proflavine; $O$, cytoplasmic-RNA adenine in the presence of proflavine.

activity continues to enter cytoplasmic RNA for some hours (Watts, 1964b). This 'pool' effect was present in the control cultures in Figs. 7 and 8 but was almost completely suppressed by proflavine. There was a small initial rise in the total radio. activity in cytoplasmic RNA in the presence of proflavine and the specific activity of the adenine in cytoplasmic RNA showed no detectable rise, but after about $2 \mathrm{hr}$. both curves fell sharply.

(iii) The rapid loss of radioactivity from nuclear RNA was not associated with a corresponding rise in the amount of radioactivity in cytoplasmic RNA when proflavine was present. There was thus no appreciable transfer of the rapidly labelled nuclear RNA in a stable form to the cytoplasm.

When the cells were grown for $2 \mathrm{hr}$. in medium containing $\left[8{ }^{14} \mathrm{C}\right]$ adenine and then transferred to non-radioactive medium containing proflavine, the result was similar to that shown in Fig. 8. The specific activity of adenine in cytoplasmic RNA showed no initial 'pool' effect and fell between 1 and $3 \mathrm{hr}$. to a level that then remained constant. The specific activity of the adenine in nuclear RNA fell sharply during the first hour, slowly between 1 and $3 \mathrm{hr}$., and then fell steeply once more.

Fig. 9 shows an experiment in which the cells were grown for a long period $(18 \mathrm{hr}$.) in medium containing $\left[8 .{ }^{14} \mathrm{C}\right]$ adenine and then transferred to non-radioactive medium. The main features of the control curves have been discussed previously

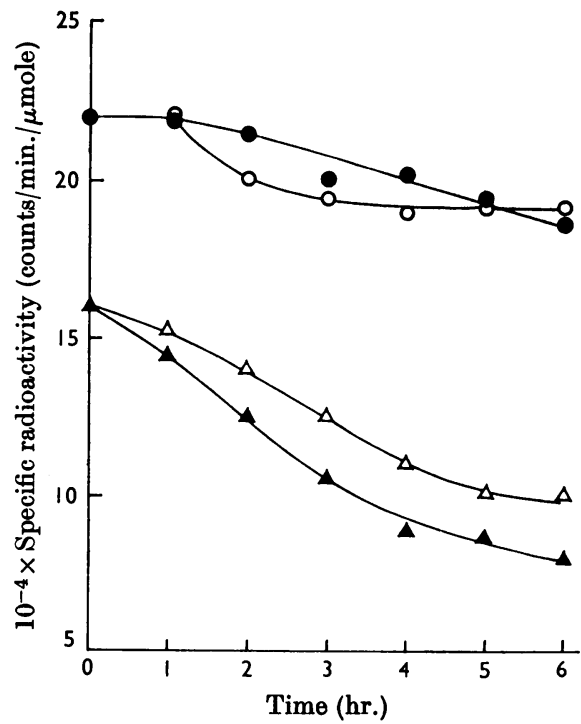

Fig. 9. Effect of proflavine on the retention of [8-14C]adenine in the RNA of HeLa cells after prolonged labelling. The cells were grown for $18 \mathrm{hr}$. in medium containing [8-14C]adenine $(0.15 \mathrm{~mm})$ (initial specific radioactivity $2 \times 10^{5}$ counts $/ \mathrm{min} . / \mu$ mole) and then transferred to nonradioactive medium containing adenosine (1 mM), guanosine $(0.2 \mathrm{~mm})$ and proflavine $(22 \mu \mathrm{M})$. Samples were taken at intervals and the specific radioactivity of the adenine in nuclear and cytoplasmic RNA was determined. $\Delta$, Nuclear-RNA adenine of the control culture without added proflavine; $\Delta$, nuclear-RNA adenine in the presence of proflavine; $\bullet$, cytoplasmic-RNA adenine of the control culture without added proflavine; $O$, cytoplasmic-RNA adenine in the presence of proflavine.

(Watts, 1964b). When the proflavine curves are compared with those shown in Fig. 8 two points emerge.

(i) The curve for the specific activity of the adenine in cytoplasmic RNA resembled that obtained when the cells had been labelled for a short period of time. The fall in specific activity between 1 and $3 \mathrm{hr}$. was, however, relatively smaller, about $10 \%$ compared with $50 \%$ after a $20 \mathrm{~min}$. period of labelling.

(ii) The rate of loss of radioactivity from the adenine in nuclear RNA was decreased after a prolonged period of labelling. The fall in the experiment shown in Fig. 9 was $35 \%$ during $6 \mathrm{hr}$. compared with $55 \%$ during $6 \mathrm{hr}$. in the experiment shown in Fig. 8.

\section{DISCUSSION}

The results of the experiments on the retention of radioactivity in RNA show that, although proflavine caused an extensive degradation of both 
nuclear and cytoplasmic RNA, the degradation was not a completely random process. The rapidly labelled nuclear RNA was preferentially degraded and this may have occurred by the process observed in the control cultures. Since, however, there was a progressive loss of RNA from both nucleus and cytoplasm, the loss of radioactivity may have reflected the ease with which degradative enzymes could attack the different fractions of RNA rather than a normal process. Thus both the location and the physical structure of the RNA would influence the rate of breakdown.

The acridine dyes interact strongly with many polyanions (Bradley \& Wolf, 1959) and there is therefore no reason to suppose that the effect of proflavine on HeLa cells was due to a specific interaction with DNA. The similarities between the effects of proflavine and actinomycin D are thus of some interest. A comparison of the present work with the results of Reich, Franklin, Shatkin \& Tatum (1962) and Weisner, Acs, Reich \& Shafiq (1965) shows that the effects of low concentrations of both compounds on the incorporation of radioactive precursors into DNA, RNA and protein were qualitatively similar, although the amounts of proflavine used to produce equivalent effects were 100-fold greater than those of actinomycin D. The loss of radioactivity from RNA when labelled cells were transferred to non-radioactive medium containing proflavine was also similar to the effect produced by actinomycin D (Paul \& Struthers, 1963; Lieberman, Abrams \& Ove, 1963; Harris, $1963,1964)$. The action of actinomycin $D$ is thought to reflect its ability specifically to inhibit the DNA-dependent synthesis of RNA (Reich et al. 1962), and the effects produced by it have been considered to show that all RNA is made on DNA (Franklin, 1963). The similarities between the effects produced by proflavine and actinomycin $\mathbf{D}$ suggest that caution is needed when interpreting the results of experiments with these compounds. Although actinomycin D may be extremely specific in its primary action, the changes produced with it need not necessarily reflect this primary specificity and may, in part at least, be the result of a secondary and more general effect produced by disorganization of the cell.

\section{REFERENCES}

Armstrong, J. A. (1956). Exp. Cell Res. 11, 640.

Bertalanffy, L. von \& Bickis, I. (1956). J. Histochem. Cytochem. 4, 481.

Bradley, D. F. \& Wolf, M. K. (1959). Proc. nat. Acad. Sci., Wash., 45, 944.

De Bruyn, P. P. H., Farr, R. S., Banks, H. \& Morthland, F. W. (1953). Exp. Cell Res. 4, 174.

Franklin, R. M. (1963). Biochim. biophys. Acta, 72, 555.

Harris, H. (1963). Nature, Lond., 198, 184.

Harris, H. (1964). Nature, Lond., 202, 1301.

Harris, H. \& Jahnz, M. (1958). Brit. J. exp. Path. 39, 597.

Harris, H. \& Watts, J. W. (1962). Proc. Roy. Soc. B, 156, 109.

Hirota, Y. (1960). Proc. nat. Acad. Sci., Wash., 46, 57.

Lieberman, I., Abrams, R. \& Ove, P. (1963). J. biol. Chem. 238, 2141.

Morthland, F. W., De Bruyn, P. P. H. \& Smith, N. H. (1954). Exp. Cell Res. 7, 201.

Paul, J. \& Struthers, M. G. (1963). Biochem. biophys. Res. Commun. 11, 135.

Reich, E., Franklin, R. M., Shatkin, A. J. \& Tatum, E. L. (1962). Proc. nat. Acad. Sci., Wash., 48, 1238.

Robbins, E. \& Marcus, P. I. (1963). J. Cell Biol. 18, 237. Saunders, A. M. (1964). J. Histochem. Cytochem. 12, 164. Schaffer, F. L. (1962). Virology, 18, 412.

Schaffer, F. L. \& Hackett, A. J. (1963). Virology, 21, 124. Scholtissek, C. (1965). Biochim. biophys. Acta, 103, 146.

Watts, J. W. (1964a). Biochem. J. 93, 297.

Watts, J. W. (1964b). Biochem. J. 93, 306.

Weisner, R., Acs, G., Reich, E. \& Shafiq, A. (1965). J. Cell Biol. 27, 47.

Wolf, M. K. \& Aronson, S. B. (1960). J. Histochem. Cytochem. 9, 22. 